\title{
Power production and environmental opinions: Environmentally motivated resistance to wind power in Sweden
}

Simon Haikola and J onas Anshelm

The self-archived postprint version of this journal article is available at Linköping University Institutional Repository (DiVA):

http:/ / urn.kb.se/ resolve?urn=urn:nbn:se:liu:diva- 125196

N.B.: When citing this work, cite the original publication.

Haikola, S., Anshelm, J ., (2016), Power production and environmental opinions: Environmentally motivated resistance to wind power in Sweden, Renewable \& sustainable energy reviews, 57, 15451555. https:// doi.org/ 10.1016/j.rser.2015.12.211

Original publication available at:

https:/ / doi.org/ 10.1016/j.rser.2015.12.211

Copyright: Elsevier

http:// www.elsevier.com/

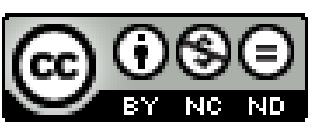


Power production and environmental opinions - Environmentally motivated resistance to windpower in Sweden Authors: Haikola, S \& Anshelm, J

Title: Power production and environmental opinions - Environmentally motivated resistance to windpower in Sweden

Published in: Renewable and sustainable energy reviews (2016), 57, 1545-1555.

Authors:

Haikola, Simon (corresponding author)

Associate professor

Linköping University

The Department of Thematic Studies - Unit of Technology and social change

SE-581 83

Sweden

simon.haikola@liu.se

phone: 0046-706316928

Anshelm, Jonas

Professor

Linköping University

The Department of Thematic Studies - Unit of Technology and social change

SE-581 83

Sweden

jonas.anshelm@liu.se

phone: 0046-13282265 
Power production and environmental opinions - Environmentally motivated resistance to windpower in Sweden Authors: Haikola, S \& Anshelm, J

\begin{abstract}
Historically, every form of large scale power production in Sweden has given rise to organised, sustained and partly successful resistance motivated by environmental arguments. Since wind power is identified by the Swedish Parliament as an important energy source for the future and the wind power industry is expected to expand on a large scale, there is reason to believe that the already existing environmental opposition to wind power will continue to grow and will attempt to limit or at least partly obstruct the wind power expansion. In order to facilitate an understanding of this opposition and its possibility to significantly influence future wind power expansion in Sweden, this paper draws upon previous research on the opposition towards hydropower, nuclear power and biomass in Sweden, and discusses these findings in relation to previous research on wind power opposition.
\end{abstract}

\title{
1. Introduction
}

This paper sets out to qualitatively compare the active resistance formed historically in Sweden towards the country's four main energy sources, with a focus on the resistance towards wind power. EU environmental policy and directives since the turn of the millennium oblige member states to increase their efforts to develop renewable energy sources and to adjust their energy systems in line with scientific climate warnings. In Sweden, wind power is currently widely regarded as the most promising energy source if the country is to continue on the road to economic growth with low carbon emissions. The European Wind Energy Association claims that as much as $563 \mathrm{TWh} /$ year may be generated within the union by 2030 [1]. The Swedish parliament has set a target of $30 \mathrm{TWh} /$ year to be generated in Sweden by the year 2020 [2]. 
Power production and environmental opinions - Environmentally motivated resistance to windpower in Sweden Authors: Haikola, S \& Anshelm, J

However, history shows that every large-scale energy enterprise in Sweden has been met with widespread protests and the formation of significant environmental opinion groups. In fact, the history of Sweden's energy policy might be told as a story of intense and at times highly successful environmental protests. Each of the three energy forms that constituted the main part of the national energy mix before the year 2000 - hydropower, nuclear power and biomass - faced organised protests when they had already expanded on a large scale. It appears that the same pattern is being repeated in the case of wind power [3]. This article compares the environmental opposition to wind power with the opposition that arose against the other main energy sources in Sweden. We do not attempt to draw any policy lessons in order to facilitate further wind power expansion; there is already a substantial literature on public wind power perceptions that serves this purpose [3-6]. Instead, we aim to draw conclusions as to what separates the environmental opposition to wind power from the other kinds of environmental oppositions that have been formed in Sweden, and regarding to what extent this opposition is likely to be able to significantly influence future wind power expansion.

A brief methodological discussion is followed by an analysis of the main objections to hydropower, nuclear power, biomass and wind power. We then compare the environmentally motivated objections to wind power with the objections to the other three power sources. 


\section{Materials and method}

This article is based on previous research, our own as well as that of others, on the environmental opinions in question. Each energy source has been studied separately before, but there has been no comparison of the opposition to wind power with the opposition to other sources of power. Therein lie the novelty and the main value of this article. The study is limited to the Swedish context and therefore we make use primarily of studies on Swedish environmental opinion. However, we relate to international studies in relevant cases, in particular in the discussion in order to lend it weight. It should further be noted that this is not a study of public perceptions of different energy sources, but of qualitative aspects of organised and active environmental opinions, and what sets them apart from each other. Therefore quantitative opinion surveys of energy preferences, of which there are plenty, e.g. [712], largely fall outside the scope of this review.

From a vast body of separate studies, we have singled out and compared the environmental arguments with regard to hydropower, nuclear power, biomass and wind power, highlighting differences and similarities between the arguments advanced. Specific attention has been devoted to the way wind power production is framed within the critical environmental debate in relation to the focus of former environmental conflicts regarding power production. We have specifically pointed out what is unique in the opposition to wind power. 
Power production and environmental opinions - Environmentally motivated resistance to windpower in Sweden Authors: Haikola, S \& Anshelm, J

\section{Results}

\subsection{Environmental opposition to hydropower}

In the early 1950 s, Sweden was faced with electricity rationing on several occasions.

The directors of the state-owned power company, Vattenfall, estimated that there was a need to increase national electricity production by $6-7 \%$ annually in order to service expanding industries and increasingly energy-consuming households. However, wide-ranging plans for the expansion of hydropower soon faced resistance from groups such as the Society for Nature Conservation, the Swedish Tourist Association and the Society for the Protection of the Landscape (Hembygdsföreningen). In the decades to follow, environmental opposition would grow, enrolling influential elites in its cause and reaching all the way to parliament. The so-called battle of the Vindel River in the 1960s, the first large environmental conflict in Swedish history, resulted in the conservative parties and the Swedish leftcommunist party voting against the plans for hydropower expansion, signalling the first real political breakthrough for environmental opinion. State reports on hydropower in the 1970s based their line of argument more or less wholesale on the 1950's environmental critics, and in 1972 the four main rivers in the country that 
Power production and environmental opinions - Environmentally motivated resistance to windpower in Sweden Authors: Haikola, S \& Anshelm, J

remained unexploited were exempted from hydropower expansion. This exemption was written into the Natural Resources Law in 1986 and was further strengthened by a parliamentary decision in 1993, in which the protection was expanded to encompass a further thirteen streams [13; cf. 14].

While there are crucial demographic, geographic, economic and institutional differences between Sweden and other countries with a significant hydropower industry that make a comparison between their respective environmental opinions precarious, there is a clear parallel in the shifts in discursive framing that the industry has gone through in Sweden and around the world. The successful framing by the Swedish hydropower resistance of the industry as environmentally unsustainable, as crystallised by the parliamentary decisions of 1986 and 1993, has been mirrored by massive protests against hydropower development in developing nations, focused on both environmental and social issues. These protests led to a significant decrease of World Bank lending to hydropower projects and in 2000, the global resistance scored an important victory with the World Commission of Dams' declaration of large dams being environmentally and socially unsustainable [15-19]. With the ascendance of the climate threat on the global environmental agenda, however, hydropower has been recast in the 21st century as a source of green power, undermining many of the arguments put forward by the resistance both in Sweden and globally. In the former, this has given rise to a somewhat paradoxical situation in which hydropower is being promoted by the government as a sustainable source of energy while still being 
Power production and environmental opinions - Environmentally motivated resistance to windpower in Sweden Authors: Haikola, S \& Anshelm, J

banned in law from further expansion. In many developing nations the reframing of hydropower has led to renewed impetus for large-scale projects, giving rise to a new round of social resistance [20-29].

An important element of the resistance against hydropower development in developing and newly dominant economies has been an appeal to indigenous rights. In Sweden, however, the case has been different. While conflicts between the indigenous Sami population of the north and the state-owned hydropower industry were indeed frequent in the 20th century, arguments pertaining to indigenous rights were largely lacking from the environmental resistance that eventually gained ground in the parliament, as we shall see in the following [30,31].

Certain aspects of the environmental opposition to hydropower stand out as significant. One of its most striking developmental features is its translation of the original arguments into objective scientific arguments. The opposition of the 1950s was rooted largely in aesthetic concerns. It was argued that nature offered sublime and existentially crucial experiences that could not be quantified or measured in objective calculations. Such experiences of immeasurable value, claimed the opposition, were being sacrificed on the altar of short-sighted economic growth. However, it was not until they began downplaying the aesthetic and subjective arguments in favour of more objectivistic ways of reasoning that the opponents of hydropower gained any political ground. Those protesting the planned exploitation of the Vindel River did so on the grounds that the river was an important scientific 
Power production and environmental opinions - Environmentally motivated resistance to windpower in Sweden Authors: Haikola, S \& Anshelm, J

resource for the University of Umeå, and that this resource would be irreversibly destroyed by any expansion of hydropower. This line of reasoning was strengthened by the argument that the river would be a significant economic resource as a site for tourism. This objectivist, scientific approach gained further importance in the 1980s when the opposition to hydropower drew on the international scientific community's calls for the preservation of biodiversity. In this context, it could be claimed that the expansion of hydropower threatened not only national but also global interests. Thus, by the 1990s the environmental opponents of hydropower had managed to translate their subjective value judgments into scientific knowledge claims [32].

There is also reason to consider the importance of which societal groups spoke out against hydropower. On a national level, protests were put forward by people from different social elite groups. Researchers, culture workers, journalists, newspaper editors and politicians joined with organised environmental groups in proclaiming the importance of preserving the main rivers both in the national interests of research and the economy and in the global interest of biodiversity. ${ }^{1}$ Parallel to this elite opinion formation was a movement of local action groups protesting the exploitation of minor streams in their immediate vicinity, putting pressure on local government. Because the waterways protected by such groups were small, these protesters did not have recourse to the scientific arguments and claims of national and even global

\footnotetext{
${ }^{1}$ See also Burningham [33] about the importance of being able to presenting one's position in an environmental conflict as "credible, robust and convincing" (p.55).
} 
Power production and environmental opinions - Environmentally motivated resistance to windpower in Sweden Authors: Haikola, S \& Anshelm, J

interests raised by the elite opposition, yet they were highly successful in hindering development plans [32].

It is also important to highlight the promise of nuclear power as a crucial condition for the coherence and persuasiveness of the environmental opposition to hydropower. By referring to scientific knowledge pointing to the vast potential in the new fission technology, opponents of hydropower could argue that there was no need to destroy valuable and beautiful rivers. This approach also enabled them to avoid questioning the growth imperative, something that would probably have made their cause nigh on impossible to defend. Not only did nuclear fission provide them with a believable alternative, but it also allowed them to portray their own stance as modern and progressive, while the proponents of hydropower were conservative and backward $[33,13]$.

Finally, one should remember that the environmental opposition to hydropower was part of a broader environmental awakening in Sweden. It gained impetus from this social shift, while also playing an important part in the formation of modern environmentalism.

\subsection{Environmental opposition to nuclear power}

In 1972 , the same year that the first nuclear reactor became operational in Oskarshamn on the Swedish Baltic coast, the Centre Party began to critique the new 
Power production and environmental opinions - Environmentally motivated resistance to windpower in Sweden Authors: Haikola, S \& Anshelm, J

technology in parliament. Nuclear power, which up to that point had been widely hailed by power companies, political parties and even the Society for Nature Conservation as the energy source of the future, suddenly became the object of massive protests from researchers, writers, journalists, engineers and politicians. The daily newspapers were flooded with critical debate. The acrimonious political debate that followed culminated in the referendum in 1980 and the subsequent parliamentary decision to phase-out nuclear power by the year 2010, a mere eight years after the first plant had started operation, and before some of the already built reactors had even been put into operation $[34,35]$. Similar developments in roughly the same time periods, with an initial, massive atomic hype transformed relatively quickly into widespread resistance and critique, can be seen in the nuclear power history of many other industrialised countries, albeit with somewhat differing framings and successes [36-40].

The critique of nuclear power in the early 1970 s was heavily focused on the risks posed to human health. The argument centred on the irresponsibility of leaving a "nuclear legacy" for generations to come, in the form of radioactive waste for which there was no adequate storage technique. This line of reasoning was often related to a critique of the perceived hubris of industrial society, thoughtlessly rampaging into the future. It would eventually be put into a broader ecological context that encompassed not only human health but also more generally environmental considerations. In that context, nuclear power stood out as the symbol of arrogant 
Power production and environmental opinions - Environmentally motivated resistance to windpower in Sweden Authors: Haikola, S \& Anshelm, J

and ruthless materialism. The Harrisburg accident in 1979 then put reactor safety issues and the risk of a meltdown in the foreground, further underlining the image of nuclear power as antithetical to a harmonious relationship between society and nature [41]. At the time of the 1980 referendum, not even the proponents of nuclear power mentioned its relatively limited environmental impact, an argument frequently raised only a few years previously [34].

The phase-out decision defused an issue that stands out as the most controversial environmental and political matter in modern Swedish history. However, local conflicts arose in conjunction with the search for suitable locations for nuclear waste storage. More or less every attempt by the Swedish Nuclear Fuel and Waste Management Company (SKB) - a joint venture between the power companies -met with fierce resistance from local action groups using civil disobedience. These groups protested not only the idea of storage facilities being located in their specific community but also the idea of long-term storage in itself, arguing that the risk of environmental contamination was too high. The claim by the nuclear industry and its associated scientific experts to be able to guarantee the safety of waste material that would be hazardous for 100000 years was perceived by the protesters as supreme technological hubris. The protests seemed to be justified by events in Ukraine in April 1986, which once again triggered organised anti-nuclear opposition on a national level [42, cf. 43]. In 1988, parliament ruled that the nuclear phase-out would begin by putting the first two reactors out of operation in 1995 and 1996 respectively [44]. 
Power production and environmental opinions - Environmentally motivated resistance to windpower in Sweden Authors: Haikola, S \& Anshelm, J

However, towards the end of the 1980s, voices were being heard arguing that a nuclear phase-out was irresponsible in the context of growing global concern about greenhouse gases. Suddenly, nuclear proponents found themselves with an environmental trump card in their hand. In comparison to what appeared increasingly to be the biggest environmental threat of all times, the technical problems associated with reactor safety and nuclear waste storage could be regarded as superficial $[45,14$, 34]. Admittedly, the reframing of nuclear power as a green technology would not be done overnight, and the phase-out seemed to have begun with the closing of two reactors around the turn of the millennium. However, when the climate threat took centre stage on the environmental political scene in 2006, it allowed for the restoration of nuclear power as a legitimate energy alternative, [46-48], a turnaround also noticeable in public perceptions and among governments internationally [49-54, 9]. Editorials put forward the message of an inevitable nuclear renaissance, and in 2009 the conservative government announced their decision to allow the establishment of new nuclear plants. The government policy for sustainable growth put nuclear power and renewables on an equal footing in the energy market, and the results of the national elections in 2010 suggested popular approval [55, 56]. After 2002 , the issue of the environmental hazards posed by nuclear power has been raised more or less solely by environmental organisations in discussions about technical and scientific aspects of waste storage [44]. However, recent years have seen the renewed governmental interest in nuclear power significantly dampened, without any 
Power production and environmental opinions - Environmentally motivated resistance to windpower in Sweden Authors: Haikola, S \& Anshelm, J

noticeable change in public opinion. Whether the Fukushima disaster in 2012 had any impact on public perception or energy policy, as it did in several other European countries [57-60,36], remains to be seen, but both institutional pressure-primarily in the form of raised taxes-and market pressure - i.e. cheaper alternatives - have led to a drastic worsening of the outlook for the future of Swedish nuclear power industry [61].

\subsection{Environmental opposition to biomass}

Going into the 1990s, the door had been closed on an expansion of every kind of large-scale power source that had been tried and tested. The major rivers were protected against expansion, and in 1988 two different parliamentary decisions determined a starting date for the phase-out of nuclear power and a cap on the use of fossil fuels. The question of how to provide energy for the country within the foreseeable future proved a difficult one for the Social Democratic government to answer, leading it to conclude an energy policy agreement with the Liberals and the Centre Party in 1991. The agreement meant that the liquidation of nuclear power was postponed and that renewable energy sources would be developed to eventually completely replace all finite resources. At that time biomass was widely considered to hold by far the largest potential. The parliament decided to invest 3.8 billion SEK over a five-year period in the development of renewables, with the lion's share devoted to 
Power production and environmental opinions - Environmentally motivated resistance to windpower in Sweden Authors: Haikola, S \& Anshelm, J

research on and development of a large-scale infrastructure for heating municipalities through the burning of biomass. Throughout the first half of the 1990s, there was a consensus in parliament that biomass would be a key component of Swedish energy policy in the future [56].

However, towards the latter half of the decade, voices began to be heard questioning the notion that biomass were an ecologically sustainable energy source. Environmental organisations such as the World Wildlife Fund (WWF), the Organisation for Swedish Ornithologists (SOF) and the Society for Nature Conservation (SNF), the latter of which had previously been positive to biofuel production, all warned that biofuel outtake threatened various forest species and degraded the landscape. The critique was echoed by professional entomologists. The organisations claimed that the rationale behind biofuel development had been overly focused on emissions and that insufficient attention had been paid to other kinds of environmental threats. The two largest daily newspapers in Sweden took up the critique in their editorials and spread it further. The risk of irreparable damage to biodiversity was simply too great, asserted the newspapers, to make the energy transition defensible $[62,63]$. The protests from the WWF and SOF also provided ecological arguments to actors who had long been opposed to the energy transition for other reasons. So, for example, one could encounter the unfamiliar sight of the Federation of Trade Organisations (Industriförbundet) expressing ecological concerns. 
Power production and environmental opinions - Environmentally motivated resistance to windpower in Sweden Authors: Haikola, S \& Anshelm, J

Besides the arguments about biodiversity and landscape degradation, there was also a debate on the possible hazards of toxic emissions from the burning of biomass [62].

The association of biomass with serious threats to biodiversity in Swedish forests put the State Environmental Protection Agency on the defensive on the issue of energy transition. In 1997, the authority halved its estimate of a feasible energy outtake from biomass in 2010 on the basis of inadequate knowledge regarding environmental effects. However, the establishment of climate change as the number one environmental threat in the first decade of the $21^{\text {st }}$ century meant that the environmental hazards associated with biomass were downplayed. Forest biodiversity and landscape preservation had no priority in the face of climate apocalypse $[14,55]$.

\subsection{Environmental opposition to wind power}

Between 1973 and 1989 wind power was evaluated in several state reports as a possible replacement for nuclear power. Two main arguments against its large-scale development were raised in the reports: the low generative capacity of wind power and its degradation of the visual environment. The sustainability argument was not emphasised in these reports [64]. Instead, great importance was attached to the aesthetic argument, and the reports concluded that the general public would most 
Power production and environmental opinions - Environmentally motivated resistance to windpower in Sweden Authors: Haikola, S \& Anshelm, J

probably not accept the visual and acoustic intrusion associated with wind power expansion $[56,64]$. As a result, several state authorities expressed great scepticism about investing in wind power. This represents the only time the political establishment and major power companies have so heavily stressed aesthetic matters with regard to energy infrastructure. The local action groups of the 2000s have all drawn upon the basic lines of critique laid down in these reports. By then, of course, the actors supplying the original critique had reversed their positions [e.g. 65].

When wind power was re-evaluated by state authorities and, after the introduction of green certificates in 2003 , by power companies, the large-scale expansion that followed gave rise to growing resistance at a local level. Protest groups joined together in forming the Union of Swedish Landscape Protection (Föreningen Svenskt Landskapsskydd), which in 2009 had 15000 members [66]. The conflict came to revolve around environmental values and whose experience and definition of a good environment should be respected. Global considerations were pitted against local interests, and expertise against lay knowledge. The large-scale development of wind power was justified by the need to mitigate global climate change. Unmoved by this rather abstract environmental threat, local action groups argued for their right to an environment unspoiled by large wind turbines. The question raised was whether global environmental considerations legitimise trampling on this right and threatening local conservation and protection interests. The more or less united expertise of biologists, ecologists, landscape planners, environmental administrators 
Power production and environmental opinions - Environmentally motivated resistance to windpower in Sweden Authors: Haikola, S \& Anshelm, J

and so forth could find no serious problems associated with the planned expansion. On the other hand, local action groups without recourse to professional knowledge argued for their right to decide on their local environment. Hence, the second question raised by the protests was whether the universal knowledge claims made by experts should be given priority over local knowledge of the environment, and how opposing claims should be arbitrated $[67-70,65]$.

The opposition to wind power has made attempts at translating what is in essence subjective, value-based reasoning into objective knowledge claims, primarily by arguing that large-scale wind power installations endanger populations of birds and bats and induce stress in people living in the vicinity. However, scientific studies have not yet shown any coherent and crucial evidence of threats either to human health $[71,65,67]$ or to biodiversity [72-81]. Thus the arguments most heavily stressed have been aesthetic, based on the individual experience of the sublime in nature and the sense of meaning and belonging associated with a particular, concrete, geographical place, leading to a focus on the need to conserve the landscape. According to this line of argument, the global climate threat does not legitimise the installation of relatively energy-inefficient wind turbines that despoil the actual natural environment of local communities in Sweden [e.g.82-86, 65, 67].

Without recourse to authoritative scientific arguments, opposition to wind power has been more or less forced to frame the resistance as an issue of localisation $[87,67$, 85]. The debate on wind power today is largely about which municipalities are 
Power production and environmental opinions - Environmentally motivated resistance to windpower in Sweden Authors: Haikola, S \& Anshelm, J

prepared to make areas available for the establishment of wind parks in the interest of the nation. For the protesters the controversy is a matter of democracy and distributive justice. The critique of wind power expansion plans is often underpinned by a notion of exploitation of peripheral areas of the country by the centre. The main beneficiaries of wind power expansion will always be the urban centres, while the poorer, sparsely populated areas are expected to sacrifice their environment while gaining little or nothing in return. From this perspective, the energy policy of the last decade is just another episode in a long history of the government riding roughshod over the less influential parts of the country. A parallel with Germany and Denmark is called for here, since these two neighbouring countries have markedly different experiences with wind power. Both have adopted a strategy of cooperative ownership, thus increasing public participation in the wind power installations. As a result, acceptance of the intrusive aspects of wind turbines has been far greater than in Sweden $[88,89,65,67,68,82,83,87]$.

\section{Discussion}


Power production and environmental opinions - Environmentally motivated resistance to windpower in Sweden Authors: Haikola, S \& Anshelm, J

\subsection{Energy supply and unquestioned growth}

Opposition to wind power in Sweden, like the opposition to hydropower up to 1972 and opposition to biomass, does not question the need for an unhindered supply of energy. There are no calls for an alternative society with decreased energy usage. The basic idea is that the energy supply must be increased, not that the existing supply must be used more efficiently. The rationality in this line of argument lies in the existence of nuclear power, which wind power proponents - like those opposing biomass - define as a practically unlimited energy source.

It is reasonable to suspect that the unwillingness to criticise high energy usage may be partly explained by the history of environmental conflict in Sweden. The highly acrimonious atmosphere surrounding the nuclear issue in the 1970s and 1980s may well have tainted arguments centred on the need to reduce energy use and resource waste, arguments that were raised by the anti-nuclear movement [e.g. 14]. Hence, opponents of wind power and biomass have been careful to stress that they are not opposing the consumer lifestyle or the paradigm of economic growth, but only the choice of energy source. The baseline of the argument against wind power and biomass is the feasibility of expanding nuclear power, making the environmental degradation resulting from large-scale renewables infrastructure totally unnecessary. On the other side of the fence, those opposing nuclear power claim that renewable energy sources will be adequate to supply the energy needed, especially if steps are taken to make energy usage more efficient, thus rendering nuclear risks an 
Power production and environmental opinions - Environmentally motivated resistance to windpower in Sweden Authors: Haikola, S \& Anshelm, J

unnecessary evil. The decision on how Sweden's energy will be generated thus becomes a question of what environmental consequences and environmental risks are to be accepted.

\subsection{Energy and political conservatism}

As Szarka $[90,91]$ points out, wind power has traditionally been associated with ecological sustainability and environmental friendliness. For three decades, it has been promoted by the environmental movement in Sweden as the green alternative to fossil fuels and nuclear power, attaining an iconic status as the key to a sustainable society [34]. The strong connection that has been made since the 1970s between wind power, effective resource management and a balanced relationship between society and nature has made it impossible for opponents of wind power to formulate a critique on the basis of a vision of societal transformation. Since the wind turbine in itself already embodies a vision of an alternative society, those who oppose wind power would first have to effectively deconstruct that connection in order to promote their own alternative vision and develop a critique of the economic growth paradigm. Instead, opposition to wind power has by necessity taken a conservative stance in the political debate on energy matters. By protesting any expansion of wind power, they must almost by definition also defend the route Swedish energy policy took up to the introduction of electricity certificates in 2003. Thus opposition to wind power becomes synonymous with support for hydro and nuclear power and the claim that 
Power production and environmental opinions - Environmentally motivated resistance to windpower in Sweden Authors: Haikola, S \& Anshelm, J

these sources of energy are environmentally sustainable. The same connection between energy policy conservatism and wind power opposition has been noticed in a study of French energy policy [92].

\subsection{Common denominators - Conflicts of scale, localisation and knowledge}

Opposition to wind power shares certain characteristics with the other energy-related environmental opinions. Firstly, all opposition to energy generation in Sweden has been critical of the size of the installations, arguing that large-scale facilities aggravate the environmental consequences associated with whichever energy source is in question [e.g. 93]. This line of critique has been a constant in Swedish environmental politics for sixty years because the energy policy of every government since the 1950s has preferred large-scale, centralised solutions. Smaller scale, decentralised production of energy has never given rise to any widespread protests, leading to the conclusion that the scale dimension is highly relevant when it comes to environmental energy opposition. This point deserves to be made - even though it might seem unsurprising - given that in the case of wind power at least, there are examples of alternative solutions in Denmark and Germany in the form of small-scale, cooperatively owned facilities [87].

Jørgensen and Karnøe have shown, for instance, how Danish wind power expansion 
Power production and environmental opinions - Environmentally motivated resistance to windpower in Sweden Authors: Haikola, S \& Anshelm, J

in the 1970s and 1980s was implemented through a bottom-up approach with decentralised, small-scale formats and relatively small facilities. The model consisted of government-sponsored cooperative ownership that saw 160000 Danish households as part-owners of the wind power industry. This seems to have fostered a widespread acceptance of the technology [94, also 95-101, 90, 91]. Szarka has also shown how a movement in Europe towards large-scale installations and increased ownership by multinational companies has reduced the possibility of gaining public acceptance of the environmental effects of wind power expansion and increased the number of environmentally motivated protests [91]. There is a vast literature covering other national contexts, highlighting and discussing the difference regarding acceptance between centralized and decentralized energy systems, and in particular the fact that high acceptance of wind power is related to ownership stake of the local community [102-107, 3, 6, 47, 93].

Another common denominator between opposition to wind power and other energy-related environmental opinions is the focus on and protest against the exploitation of environmentally sensitive areas. Opposition to hydropower grew out of the campaigns in the 1950s and 1960s to preserve certain rivers deemed to have elevated status as objects for preservation. Similarly, opposition to nuclear power grew out of protests against the localisation plans for the Barsebäck and Ringhals power plants and evolved into violent opposition to attempts at storing the nuclear waste at various locations. Opposition to wind power shares this characteristic in that 
Power production and environmental opinions - Environmentally motivated resistance to windpower in Sweden Authors: Haikola, S \& Anshelm, J

every wind power controversy has been a controversy over localisation [e.g. 89]. This is similar to wind power development and resistance elsewhere in Europe [e.g. 108, 104], and is a feature of the opposition which allows for the so called "national-local gap", by which opposition to specific wind power establishments may be combined with a positive stance towards the energy source in general [e.g. 109, 110, 98, 107]. Yet another similarity is the conflict that pits expert knowledge against lay knowledge. Power companies and state authorities have tended to enlist scientific experts who assert that the power source in question is associated with very limited, and in principle acceptable, detrimental effects on human health and the environment. By contrast, the critique of each energy source initially rested on civil society initiatives, autodidacts, and the kind of knowledge only attainable by locals familiar with the geographical place. There has thus been a conflict between universal, objectivist and abstract knowledge claims on the one hand and, on the other hand, specific claims connected to the actual place and based upon personal experience $[62,82,83,87,88]$. In other words, the environmental controversies regarding energy production have been, at least in part, conflicts between different kinds of knowledge. In the case of hydropower, nuclear power and biomass, however, the opposition has also been successful in incorporating experts and social elites in its ranks, thus adding significant weight to its arguments. So far, opposition to wind power has not gained much ground in that direction. This is one of the aspects that 
Power production and environmental opinions - Environmentally motivated resistance to windpower in Sweden Authors: Haikola, S \& Anshelm, J

set it apart from the other three energy sources. The next part of this article will discuss these differences.

Despite the similarities between the opposition to wind power and the opposition to other energy sources, one is left with the overall impression that wind power opinion is a major outlier in Swedish environmental history for the reasons discussed below.

\subsection{Chronology}

The first point of difference that catches the eye is the chronology with regard to the first appearance of the fundamental lines of critique against the power source in question. In the cases of hydropower, nuclear power and biomass, the critique was only formulated after large-scale expansion had occurred. The critique against wind power, however, was put in place by government actors and power companies well in advance of any concrete plans for large-scale wind power development. The basic arguments - mainly centred on aesthetics and visual intrusiveness - in this early, state-sanctioned critique are fundamental to environmental opposition to wind power today. Yet popular opinion surveys from the 1980s to the present have shown significant popular support for wind power expansion [64].

Not only is the timing of the critique unusual in the case of wind power, but so is the fact that it was formulated by politicians and power company representatives. As long as hydropower and nuclear power created an electricity surplus, it was rational for 
Power production and environmental opinions - Environmentally motivated resistance to windpower in Sweden Authors: Haikola, S \& Anshelm, J

them to stress the negative effects of wind power [111, 64]; the same pattern has been identified in French energy policy [92]. However, popular opposition to nuclear and hydropower radically altered the parameters, and in the context of climate threat warnings and the $\mathrm{EU}$ directive on renewables, the parliament and the power companies re-evaluated the future of wind power. The mantle of critique was picked up by local action groups in the communities affected by the newly made expansion plans.

\subsection{Lack of national support}

Despite the preparatory critique laid out by parliament and power companies, the awakening environmental opposition to wind power in the first decade of the 2000s failed to gain any traction among the main political parties. There was consensus in parliament on the large-scale expansion plans, and since the introduction of electricity certificates made wind power commercially appealing, the power companies viewed it as a power source with large potential [65, 84, 85, 89]. Nor did any of the major opinion formers in society join the ranks of those opposing the expansion of wind power. Trade unions, trade organisations and the large daily newspapers remained deaf to the protests. Crucially, the main environmental 
Power production and environmental opinions - Environmentally motivated resistance to windpower in Sweden Authors: Haikola, S \& Anshelm, J

organisations took a positive stance towards wind power as a relatively sustainable source of energy [3, c.f. 91].

The lack of general support for opposition to wind power is highlighted by the fact that not even the Organisation of Swedish Ornithologists protested the expansion plans, although they had focused on the hazards to birdlife due to biofuel production (c.f. [91], where the opposite picture is painted regarding the rest of Europe). This total lack of support for an environmental opinion among all major societal opinion formers is historically unique, yet it is part of a pattern recognisable in other European nations with wind power experience, such as Denmark, France and the UK $[112$, c.f. 90$]$. There is a historical parallel in the early opposition to hydropower in Sweden, which lacked the support of parliament and interest organisations. Still, that opposition stood on the firm foundation of the Swedish Society for Nature Conservation, which included diverse national elites such as university professors, journalists, lawyers and writers. They eventually managed to make an impact on parliament.

Furthermore, opposition to wind power has failed to gain the support of the scientific community, whereas the opponents of other energy options managed to enrol biologists, ecologists, toxicologists, doctors, entomologists, physicists, hydrologists and geologists in their cause. Despite some attempts by wind power opponents to translate their arguments into scientific knowledge claims - mainly by arguing for disturbances to the ecosystem, hazards to human health and threats to 
Power production and environmental opinions - Environmentally motivated resistance to windpower in Sweden Authors: Haikola, S \& Anshelm, J

endangered species - the breakthrough in research support has so far proved elusive [72-83, 85, 89]. Again, comparison with the opposition to hydropower is enlightening, for it was the transition from aesthetic claims to scientific knowledge claims in the 1960s that saw this movement start to gain influence. At present, there seems to be a consensus in the research community on the relatively limited environmental effects of wind power. This harmonious academic situation contrasts with the debate in regard to the other energy sources, which was characterised by acrimonious conflicts between different research groups.

A closer look at the spokespersons for each environmental opinion further highlights the problem faced by opponents of wind power with regard to the possibilities of increasing their influence. In the case of hydropower, the protests were led by highranking lawyers, professors from the natural sciences and journalists. They had the contacts, authority and acknowledged competence necessary for making a major impact on parliamentary politics. The opposition to nuclear power was different in that it had a wider popular basis and included a significant number of laypersons, but here too a major contribution was made by social elites such as internationally acknowledged physicists, doctors, journalists and well-known writers, legitimising the critique that was eventually taken up by parties in parliament. The protests against biomass, in their turn, were spearheaded by ornithologists, biologists and entomologists who gained the support of national environmental organisations such as the World Wide Fund for Nature (WWF) and the Organisation of Swedish 
Power production and environmental opinions - Environmentally motivated resistance to windpower in Sweden Authors: Haikola, S \& Anshelm, J

Ornithologists. They were subsequently supported by editorials in the large daily newspapers, by trade organisations and by the forest industry. Opposition to wind power, however, has been articulated almost exclusively on a local scale by action groups and local inhabitants, fishermen, Saami people and the owners of weekend cottages $[65-70,83,89]$. Admittedly, these protests have at times gained the support of a well-known writer or politician with a connection to the specific geographical place being exploited. They have sometimes been successful in enrolling municipal politicians in their cause, but overall they have lacked the crucial support of national elites. If opposition to wind power had enjoyed the support of even a fraction of those politicians, power company representatives, governmental agencies and energy experts who argued against wind power expansion in the 1970s and 1980s, the odds would probably have changed dramatically in their favour. As it stands, the odds seem stacked against them.

\subsection{A conflict between environmental values}

Another unique aspect of the opposition to wind power, and one that may further damage its chances of gaining wider support, is the conflict that exists between the environmental values it is said to favour and those it is said to endanger. The rationale behind developing wind power on a large scale is its apparent sustainability. Unlike the other main energy sources, it does not jeopardise the survival of any species of animals, it is not associated with resource depletion, it does not lead to 
Power production and environmental opinions - Environmentally motivated resistance to windpower in Sweden Authors: Haikola, S \& Anshelm, J

climate change, and it does not pollute the environment $[65-69,83,86]$. The primacy of the climate threat on the political environmental agenda in the recent decade, especially, has forced wind power opponents into a specific kind of argumentation [14]. Szarka has termed this wind power's "environmental frame" [91], and the generally positive, sustainability framing of wind power has been pronounced also in public perception surveys in both the US and Europe $[113,114,7,10,11]$. The other main power forms are associated with some or all of these environmental effects, and thus, the arguments against the other energy sources are equal to the arguments for wind power. This means that the avenues for arguing against wind power on the grounds of ecological sustainability are severely limited. Instead, opposition to wind power has focused on arguments about audio-visual degradation, mobilising aesthetic environmental values against the scientific, objectivist arguments of the proponents of wind power. The major themes of the wind power protests in Sweden are subjective experiences of a sublime nature, of beauty and of an unspoiled landscape and the value of preserving a traditional, cultural landscape for the inhabitants of the geographical places where wind power expansion is planned, a framing noticed in the international research as well $[115-118,106] .{ }^{2}$ The value of the cultural landscape is also commonly elevated into an issue of national interest, as it is portrayed as an important foundation of a collective identity and an anchorage in national history. A landscape where $30 \mathrm{TWh} /$ year are produced by wind turbines is

\footnotetext{
2 Toke et al [98] conclude that effective opposition to wind power establishment is always rooted in "landscape values", in a term a that encompasses more than aesthetical aspects.
} 
Power production and environmental opinions - Environmentally motivated resistance to windpower in Sweden Authors: Haikola, S \& Anshelm, J

largely ruined, according to those protesting the expansion of wind power. The strong emphasis on subjective experience sets the opposition to wind power apart from other energy-related environmental opinions [119, 120, 65, 82-85, 89].

\subsection{The now and the here}

Despite attempts by opponents of wind power to highlight issues of biodiversity and animal protection, their main line of critique has been based on anthropocentric values. Their arguments are very individualistic and existentially oriented, focusing on the individual's right to a sense of belonging in the landscape. Their case can be characterised as liberal discourse in which freedom from intrusion is weighed against the environmental and energy political demands of central planning. According to the opponents of wind power, the national and global environmental concerns that drive wind power expansion may either be accommodated in other ways or they simply do not merit the perceived harm to individuals' health and existential wellbeing $[65,67-69,83-85,89]$. The contrast in this regard is the most marked when opposition to wind power is compared to opposition to nuclear power, which stresses totally different values relating to future generations and the continued existence of ecosystems. Wind power protesters share some common ground with the hydropower opposition in the arguments that centre on the individual experience of nature and the value of preserving the landscape but, unlike the former, the latter 
Power production and environmental opinions - Environmentally motivated resistance to windpower in Sweden Authors: Haikola, S \& Anshelm, J

may also focus on the issue of national research interests and the global interest in protecting biodiversity.

Thus, environmental opposition to wind power places itself firmly in a local context, drawing its system limits around a specific locality and presupposing that global concerns about the environment may be better addressed by other technological means and on an international level. The sacrifice of the Swedish cultural landscape for the sake of global environmental concerns is deemed to be neither fair, adequate nor reasonable $[65,82-85,89,119,120]$. This forced choice for wind power opponents between a local form of green value and another, more universal one, has been noticed also in other national contexts [e.g. 121]. The system boundaries of the other energy-related environmental opinions are drawn quite differently. In the case of biomass, the protests have no special affinity with a locality but focus instead on the national interest of preserving Swedish flora and fauna. Similarly, the main branch of the opposition to hydropower since the 1950s has been arguing from and for a national perspective, which since the 1980s has been complemented with international arguments about biodiversity and biotope protection. Opposition to nuclear power has, of course, been planetary in scope since its very beginning. As compared to the other environmental opinions, opposition to wind power is very much focused on the present [e.g. $65,82-85,89]$. Whereas protesters against hydropower, biomass and nuclear power argue for the preservation for future generations of, respectively, unique biotopes in the rivers, rare forest species and the 
Power production and environmental opinions - Environmentally motivated resistance to windpower in Sweden Authors: Haikola, S \& Anshelm, J

earth as a whole, the opponents of wind power stress the well-being of people in the here and the now. The present is juxtaposed to the future, and the clearly delimited, concrete locality to a distant, abstract and elusive global context.

Another aspect of this spatiotemporal dimension of the different energy critiques is the reversibility of the associated environmental consequences. One of the strongest arguments against hydropower is the fact that the rivers will be altered forever once the power infrastructure is in place. Likewise, the protests against biomass focus on the difficulty or impossibility of restoring forest biodiversity. Opponents of nuclear power stress the vast timespan required for the decay of nuclear waste. Opponents of wind power do not have this irreversibility argument as readily available, since it should, at least in theory, be possible to dismantle wind turbines without irreparable harm to ecosystems. However, they could plausibly argue for a different kind of irreversibility, namely the irreversibility of the harm done to individuals' existential well-being in the present. The damage to locals' experience of belonging in a landscape may not be reparable even if the infrastructure responsible for the damage might be dismantled sometime in the abstract future. Yet, on this point too, opposition to wind power seems to be facing an uphill struggle as the irreversibility of the damage associated with the other energy sources has been firmly established in the popular, political and scientific discourse [112].

In the visualisation below (fig. 1), the characteristics of each environmental opinion are contextualised on a spatiotemporal map, showing how their arguments relate to 
Power production and environmental opinions - Environmentally motivated resistance to windpower in Sweden Authors: Haikola, S \& Anshelm, J

the present/future and to the scale dimension ranging from the local to the global.

The visualisation is illuminating in that it succinctly demonstrates how opposition to wind power separates itself from the others. Whereas all the opposition to the other environmental energy options relates more or less explicitly to future generations and to a wider context, ranging from a national to a global perspective, the opposition to wind power is very much situated in the present and in the local geographical place. Most striking, of course, is the contrast between the opposition to wind power and to nuclear power, the latter orienting itself on a global scale and at least 100000 years into the future. (For an international discussion about the spatiotemporal dimensions of environmental justice issues in the case of wind power instalments, see [122-127]). 
Power production and environmental opinions - Environmentally motivated resistance to windpower in Sweden Authors: Haikola, S \& Anshelm, J

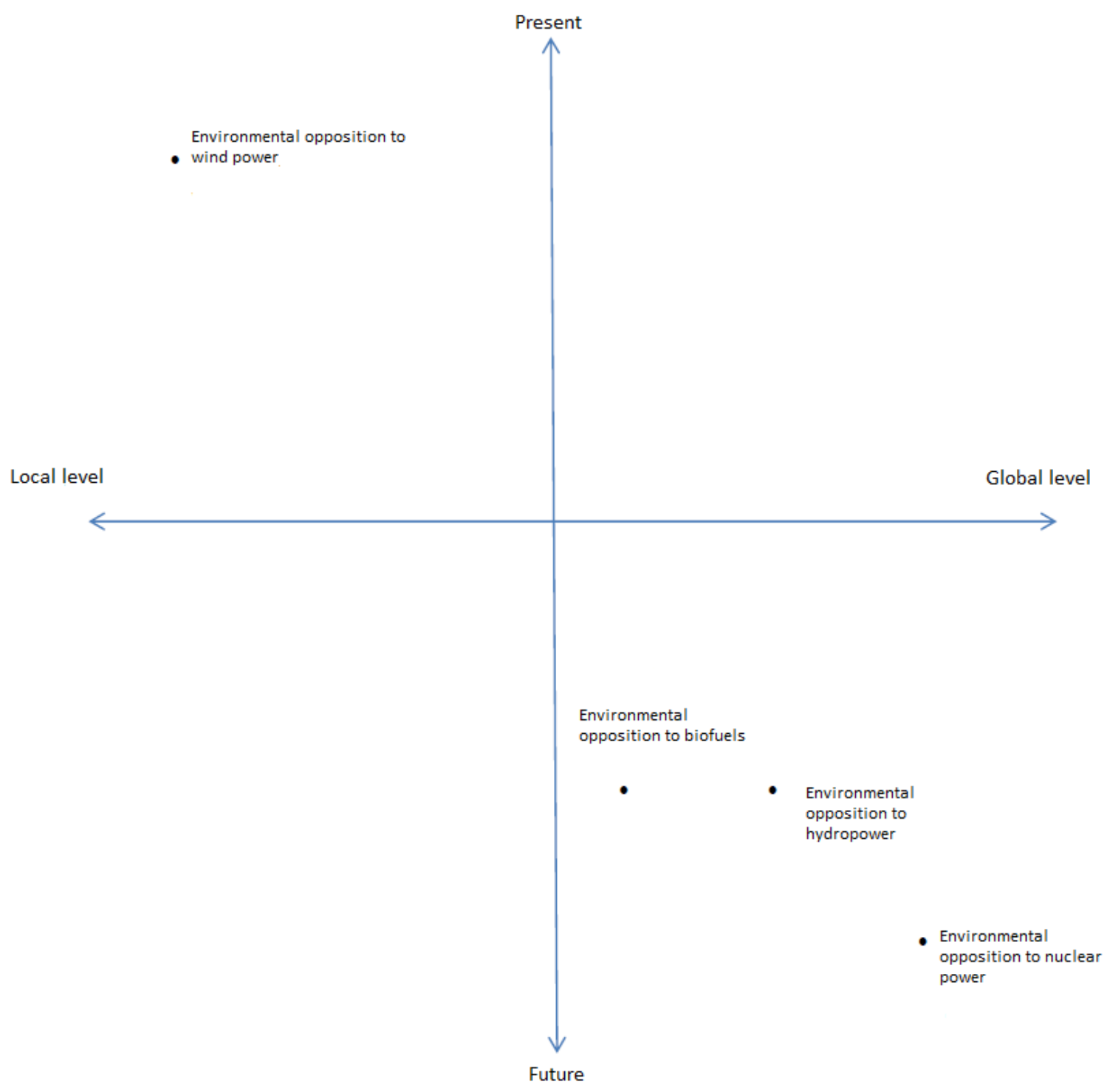

Figure 1: Visualization of how different environmental opinions relate to issues on a global/local and a future/present scale. 
Power production and environmental opinions - Environmentally motivated resistance to windpower in Sweden Authors: Haikola, S \& Anshelm, J

\subsection{Competing definitions of "the environment"}

If the choice of energy source is also a choice of which environmental consequences should be deemed more acceptable, it follows that those holding the environmental opinions discussed in this article differ in their definitions of what "the environment" is, since they all claim to prioritise the environment in their arguments. Yet another problem for those who oppose wind power is the fact that their concept of the environment seems to differ from the dominant concept of it in the public mind, among the environmental organisations and among the main political parties. The latter groups deem wind power to be a relatively environmentally friendly source of energy, associated with no or negligible damage to the environment. Environmental damage, according to this concept of the environment, is understood as pollution of the air, soil and water, depletion of limited natural resources, reduced biodiversity and disturbance of global as well as local ecosystems. The protection of human health and the reproductive ability of ecosystems, and also the preservation of specific species and biotopes, is at the centre of this understanding of the environment.

The understanding of the environment within the wind power critical discourse is radically different. Here a good environment is understood as a delimited geographical location preserved from the intrusion of external elements, and the fundamental ambition is to safeguard a certain landscape and its associated existential values $[128,65]$; the same landscape protection prerogative among wind 
Power production and environmental opinions - Environmentally motivated resistance to windpower in Sweden Authors: Haikola, S \& Anshelm, J

power opponents is pronounced internationally as well [e.g. 92, 106]. Environmental protection in this sense is understood first and foremost as the conservation of relatively untouched places of cultural-historical value that have a deep meaning for the local community. Thus, the opposition to wind power is part of a more than century old Swedish social movement aimed at nature conservation [129, 130]. Rather simplistically, one may define opposition to wind power as mainly devoted to nature conservation and landscape protection, whereas opposition to nuclear power focuses on ecological megathreats. Opposition to hydropower and biomass, in their turn, is mainly directed towards the protection of biotopes and biocentric values.

Interestingly, in this way landscape conservation and energy conservatism has walked hand in hand within the Swedish wind power opposition, a connection noticed also in the French context $[92,104]$. It seems certain that the existence of established nuclear industries in both countries have served to strengthen this connection.

This discussion of different environmental concepts and values is not merely a theoretical game. These differences have important political implications. Given that biomass are used mainly for the production of heat, and that further hydropower expansion is forbidden by law, the current political discussion with regard to electricity sets wind power against nuclear power. Those who protest any expansion of wind power from the perspective that environmental protection is mainly an issue of landscape protection are more or less forced to argue in favour of nuclear power. Opponents of wind power are thus most often proponents of nuclear power $[6,12$, 
Power production and environmental opinions - Environmentally motivated resistance to windpower in Sweden Authors: Haikola, S \& Anshelm, J

92]. Conversely, opponents of nuclear power argue for the comparably limited environmental effects of wind power. The likelihood of finding opponents of both power sources today is very small, except for some highly marginalised voices arguing for a shift away from the economic growth paradigm. Championing both power sources is possible, however, as evidenced by the conservative government [112].

The power to define what is a good environment and what environmental considerations and values should be prioritised is obviously important when it comes to environmental policy. Given the deep-seated perception of wind power as an ecologically sustainable energy source, opposition to it seems to be facing an uphill struggle in its attempt to gain support for its environmental concept. In a time when climate threat and ecological crisis loom large, nature conservation and landscape protection are unlikely to gain traction on a more popular or political level.

\subsection{Concluding remarks}

There is a vast literature on public perceptions of energy sources, but no consensus regarding what socio-demographic factors are most influential in determining acceptance and resistance $[131,8]$. In this review paper, we have set out to contribute to the literature on energy preferences by instead analysing how active resistance to different energy sources has been framed in Sweden, by what kind of actors the resistance has been made up and how these factors have related to changes in 
Power production and environmental opinions - Environmentally motivated resistance to windpower in Sweden Authors: Haikola, S \& Anshelm, J

energy policy. By focusing on such qualitative aspects of environmental opinions, we follow van der Horsts call for more qualitative research on the forming of environmental opinions regarding wind power [132]. We believe we are able to further the understanding of how the framing of environmental opinions matter for the development of effective environmental movements, and in what aspects the environmental opinion against wind power is unique in a Swedish context.

To summarise our discussion, the environmental opposition to wind power in Sweden is set apart from the other three environmental oppositions through its firm anchoring in the local geographical place, its appeal to aesthetic arguments and its orientation towards environmental effects in the present, a positioning to which it has been more or less forced because of the successful framing by the other environmental opinions of their respective target energy source - i.e. hydropower, nuclear power and biomass - as associated with irreversible, scientifically verifiable threats to ecological values on a national or universal level. This unique framing and the environmental opinion's lack of broad popular support and of support from influential groups, make it likely that wind power resistance in Sweden will continue to take the form of highly place-specific and localised struggles, some of which will be successful but that will not be able to transmute into a coherent and effective national environmental movement. 
Power production and environmental opinions - Environmentally motivated resistance to windpower in Sweden Authors: Haikola, S \& Anshelm, J

\section{References}

[1] EWEA. Pure power: wind energy targets for 2020 and 2030. Brussels: European Wind Energy Association; 2009.

[2] Government Proposition. En sammanhållen klimat- och energipolitik. Ministry of Enterprise Stockholm; 2008/09: 163.

[3] Fjaestad M. Winds of time: lessons from Utö in the Stockholm archipelago 1990-2001. Energy Policy 2013;62:124-30.

[4] Jolivet E, Heiskanen E. Blowing against the wind: an exploratory application of actor network theory to the analysis of controversies and participation processes in wind energy. Energy Policy 2010;38: 6746-54.

[5] Wolsink M. Planning of renewables schemes: deliberative and fair decision- making on landscape issues instead of reproachful accusations of non-cooperation. Energy Policy 2007;35: 2692-704.

[6] Breukers S, Wolsink M. Wind power implementation in changing institutional landscapes: an international comparison. Energy Policy 2007;35: 2737-50.

[7] Corner A, Venables D, Spence A, Poortinga W, Demski C, Pidgeon N. Nuclear power, climate change and energy security: exploring British public attitudes. Energy Policy 2011;39: 4823-33.

[8] Ertör-Akyazi P, Adaman F, Özkaynak B, Zenginobuz Ü. Citizens' preferences on nuclear and renewable energy sources: evidence from Turkey. Energy Policy 2012;47: 309-20.

[9] Visschers V, Keller C, Siegrist M. Climate change benefits and energy supply benefits as determinants of acceptance of nuclear power stations: Investigating an explanatory model. Energy Policy 2011;39: 3621-9.

[10] Greenberg M. Energy sources, public policy, and public preferences: analysis of US national and site-specific data. Energy Policy 2009;37: 3242-9. 
Power production and environmental opinions - Environmentally motivated resistance to windpower in Sweden Authors: Haikola, S \& Anshelm, J

[11] Pidgeon N, Lorenzoni I, Poortinga W. Climate change or nuclear power - no thanks! A quantitative study of public perceptions and risk framing in Britain. Glob Environ Chang 2008;18: 69-85.

[12] Spence A, Poortinga W, Pidgeon N, Lorenzoni I. Public perceptions of energy choices: the influence of beliefs about climate change and the environment. Energy Environ 2010;21: 385-407.

[13] Vedung E, Brandel M. Vattenkraften, staten och de politiska partierna. Nora: Nya Doxa; 2001.

[14] Nilsson M. Learning, frames and environmental policy integration: the case of Swedish energy policy. Environ Plan C: Gov Policy 2005;23: 207-26.

[15] WCD [World Commission on Dams]. Dams and development: a new framework for decisionmaking. London: Earthscan; 2000.

[16] McCully P. Silenced rivers: the ecology and politics of large dams. 2nd ed. London: Zed Books; 2001.

[17] Khagram S. Dams and development: transnational struggles for water and power. Ithaca: Cornell University Press; 2004.

[18] Rest M. Generating power: debates on development around the Nepalese Arun-3 hydropower project. Contemp South Asia 2012;20: 105-17.

[19] Dwivedi R. Displacement, risks and resistance: local perceptions and actions in the Sardar Sarowar. Dev Chang 1999;30: 43-78.

[20] Cole M, Elliott R, Strobl E. Climate change, hydrodependency, and the African dam boom. World Dev 2014;60: 84-98.

[21] Pittock J. Viewpoint: Better management of hydropower in an era of climate change. Water Altern 2010;3: 444-52.

[22] Ahlers R, Budds J, Joshi D, Merme V, Zwarteveen M. Framing hydropower as green energy: assessing drivers, risks and tensions in the Eastern Himalayas. Earth Syst Dyn 2015;6: 195-204.

[23] Baruah S. Whose river is it anyway? Political economy of hydropower in the Eastern Himalayas Econ Political Wkly 2012;47: 41-52.

[24] Huber A, Joshi D. Hydropower, anti-politics, and the opening of new political spaces in the Eastern Himalayas. World Dev 2015;76: 13-25.

[25] Finley-Brook $M$, Thomas $C$. Renewable energy and human rights violations: illustrative cases from 
Power production and environmental opinions - Environmentally motivated resistance to windpower in Sweden Authors: Haikola, S \& Anshelm, J

indigenous territories in Panama. Ann Assoc Am Geogr 2011;101: 863-72.

[26] Matthews N. Water grabbing in the Mekong basin: an analysis of the winners and losers of Thailand's hydropower development in Lao PDR. Water Altern 2012;5: 392-411.

[27] McCormick S. Damming the Amazon: local movements and transnational struggles over water. Soc Nat Resour: An Int J 2010;24: 34-48.

[28] Sneddon C, Fox C. Struggles over dams as struggles for justice: the World Commission on Dams (WCD) and anti-dam campaigns in Thailand and Mozambique. Soc Nat Resour: An Int J 2008;21: 62540.

[29] Alhassan H. Butterflies versus hydropower: reflections on large dams in contemporary Africa. Water Altern 2009;2: 148-60.

[30] Össbo Å, Lantto P. Colonial tutelage and industrial colonialism: reindeer husbandry and early 20th-century hydroelectric development in Sweden. Scand J hist 2011;36: 324-48.

[31] Öhman M-B. On visible places and invisibilized peoples: Swedish state- supported hydropower exploitation of indigenous peoples' territories. In: Baraldi E, et al., editors. Sagamore Beach, MA: Taking Place; Technology and Business, Science History Publications; 2006.

[32] Anshelm J. Vattenkraft och naturskydd. En analys av opinionen mot vat- tenkraftsutbyggnaden i Sverige 1950-1990. Linköping: Linköping University; 1992.

[33] Burningham K. Using the language of NIMBY: a topic for research, not an activity for researchers. Local Environ 2000;5:55-67.

[34] Anshelm J. Mellan frälsning och domedag. Om kärnkraftens politiska idé- historia i Sverige 19451999. Stockholm/Stehag: Symposion; 2000.

[35] Lindquist P. Det klyvbara ämnet. Diskursiva ordningar i svensk kärnkraft- spolitik 1972-1980 (diss.). Lund: Lund University; 1997.

[36] Glaser A. From Brokdorf to Fukushima: the long journey to nuclear phase- out. Bull At Sci 2012;68:10-2.

[37] Radkau J. Aufstieg und Krise der deutschen Atomwirtschaft. Hamburg: Rowohlt; 1983. p. 1945-75.

[38] Pidgeon N, Demski C. From nuclear to renewable: energy system transfor- mation and public attitudes. Bull At Sci 2012;68:41-51. 
Power production and environmental opinions - Environmentally motivated resistance to windpower in Sweden Authors: Haikola, S \& Anshelm, J

[39] Doern G, Dorman A, Morrison R. Canadian nuclear energy policy: changing ideas, institutions, and interests. Toronto: University of Toronto Press; 2001.

[40] Leeming M. The creation of radicalism: anti-nuclear activism in Nova Scotia, c. 1972-1979. Can Hist Rev 2014;95:217-41.

[41] Nohrstedt D. External shocks and policy change: three Mile Island and Swedish nuclear energy policy. J Eur Public Policy 2005;12:1041-59.

[42] Drottz-Sjöberg B-M, Sjöberg L. Risk perception and worries after the Cher- nobyl accident. J Environ Psychol 1990;10:135-49.

[43] Nohrstedt D. The politics of crisis policymaking: Chernobyl and Swedish nuclear energy policy. Policy Stud J 2008;36:257-78.

[44] Anshelm J. Bergsäkert eller våghalsigt? Frågan om kärnavfallets hantering i det offentliga samtalet i Sverige Lund: Arkiv; 2006. p. 1950-2002.

[45] Wikdahl C-E. Sweden: nuclear power policy and public opinion. More favourable attitudes toward nuclear power are emerging. IAEA Bull 1991;1:2933.

[46] Kåberger T. History of nuclear power in Sweden. Estud Av 2007;21:225-42.

[47] Hedberg P, Holmberg S. Nuclear power policy positions of the political parties. In: Swedish nuclear power policy: a compilation of public record material. Gothenburg: Department of Political Science, University of Gothenburg; 2008.

[48] Roßegger U, Ramin R. Explaining the ending of Sweden's nuclear phase-out policy: a new approach by referring to the advocacy coalition framework theory. Innov: Eur J Soc Sci Res 2013;26: $323-43$.

[49] Stoutenborough J, Sturgess S, Vedlitz A. Knowledge, risk, and policy support: public perceptions of nuclear power. Energy Policy 2013;62: 176-84.

[50] Ansolabehere S. Public attitudes toward America's energy options: insights for nuclear energy. Cambridge, MA: MIT Center for Advanced Nuclear Energy Systems; 2007.

[51] Pampel F. Support for nuclear energy in the context of climate change: evidence from the European Union. Organ Environ 2011;24: 249-68.

[52] Truelove H, Greenberg M. Who has become more open to nuclear power because of climate change? Clim Chang 2013;116: 389-409. 
Power production and environmental opinions - Environmentally motivated resistance to windpower in Sweden Authors: Haikola, S \& Anshelm, J

[53] Greenberg M, Truelove H. Energy choices and risk beliefs: is it just global warming and fear of a nuclear power plant accident? Risk Anal 2011; 31: 819-31.

[54] Stoett P. Toward renewed legitimacy? Nuclear power, global warming, and security Glob Environ Politics 2003;3: 99-116.

[55] Anshelm J. Kampen om klimatet. Miljöpolitiska strider i Sverige 2006-2009. Stockholm: Pärspektiv; 2012.

[56] Kall AS. Förnyelse med förhinder. Den riksdagspolitiska debatten om omställningen av energisystemet 1980-2010 (diss.). Linköping: Linköping University; 2011.

[57] Adam D. Parochial energy policy. Nat Clim Chang 2011;1: 230-2.

[58] Poumadere M, Bertoldo R, Samadi J. Public perceptions and governance of controversial technologies to tackle climate change: nuclear power, carbon capture and storage, wind, and geoengineering. WIREs Clim Chang 2011;2: 712-27.

[59] Visschers V, Siegrist M. How a nuclear power plant accident influences acceptance of nuclear power: results of a longitudinal study before and after the Fukushima disaster. Risk Anal: Int J 2013;33: $333-47$.

[60] Welsch H, Biermann P. Analysis: Fukushima and the preference for nuclear power in Europe: evidence from subjective well-being data. Ecol Econ 2014;108: 171-9.

[61] SvD. [Svenska dagbladet] Näringsliv. Vattenfall vill stänga Ringhals 1 \& 2 i förtid, 28/4-2015; 2015.

[62] Anshelm J. Att ersätta kärnkraften med bioenergi. Om en omstridd idé i den svenska offentliga energipolitiska debatten 1979-2000 (Program Energy Systems). Linköping: Linköping University; 2009.

[63] Löfstedt R. Sweden ś biomass controversy. Environment 1997;40(4): 16-20 42-45.

[64] Carlman I. Blåsningen. Svensk vindkraft 1973 till 1990 (diss.). Uppsala: Uppsala University; 1990.

[65] Henningsson M, Jönsson S, Bengtsson-Ryberg J, Bluhm G, Bolin K, Bodén B, et al. Vindkraftens påverkan på människors intressen. Stockholm: Vindval, Swedish Environmental Protection Agency; 2012.

[66] Jacobsson T. Ökat motstånd mot vindkraft.Focus 21/8; 2009.

[67] Klintman M, Waldo Å. Erfarenhet av vindkraftsetablering. Förankring, acceptans och motstånd. Stockholm: Vindval, Swedish Environmental Protection Agency; 2008. 
Power production and environmental opinions - Environmentally motivated resistance to windpower in Sweden Authors: Haikola, S \& Anshelm, J

[68] Söderholm P, Ek K, Pettersson M. Wind power development in Sweden.

Global policies and local obstacles. Renew Sustain Energy Rev 2007: 365- 400.

[69] Ek K. Public and private attitudes towards 'green' electricity: the case of Swedish wind power. Energy Policy 2005: 1677-89.

[70] Lawrence R. Internal colonisation and indigenous resource sovereignty: wind power developments on traditional Saami lands. Environ Plan D: Soc Space 2014;32: 1036-53.

[71] Pedersen E, Forssén J, Persson Waye K. Människors upplevelser av ljud från vindkraftverk. Stockholm: Vindval, Swedish Environmental Protection Agency; 2009.

[72] Rydell J, Engström H, Hedenström A, Kyed Larsen J, Pettersson J, Green M. Vindkraftens effekter på fåglar och fladdermöss. Stockholm: Vindval, Swedish Environmental Protection Agency; 2011.

[73] Bergström L, Sundqvist F, Bergström U. Effekter av en havsbaserad vindkraftspark på fördelning av bottennära fisk. Stockholm: Vindval, Swedish Environmental Protection Agency; 2009.

[74] Sigray P, Andersson M, Fristedt T. Partikelrörelser i vatten vid ett vindk-

raftverk. Stockholm: Vindval, Swedish Environmental Protection Agency; 2009.

[75] Andersson M, Sigray P, Persson L. Ljud från vindkraftverk i havet och dess påverkan på fisk. Stockholm: Vindval, Swedish Environmental Protection Agency; 2011.

[76] Helldin J, Jung J, Neumann W, Olsson M, Skarin A, Widemo F. Vindkraftens effekter på landlevande däggdjur. Stockholm: Vindval, Swedish Environmental Protection Agency; 2012.

[77] Sandén B, editor. Systems perspectives on renewable power. Gothenburg: Chalmers University of Technology; 2014.

[78] Edenhofer O., et al. Renewable energy sources and climate change mitigation, Special report of the intergovernmental panel of climate change; 2011.

[79] Dai K, Bergot A, Liang C, W-N., Huang Z. Environmental issues associated with wind energy: a review. Renew Energy 2015;75: 911-21.

[80] Arvesen A, Hertwich E. Assessing the life cycle environmental impacts of wind power: a review of present knowledge and research needs. Renew Sustain Energy Rev 2012;16: 5994-6006.

[81] Tabassum-Abassi M, Premalatha M, Abbasi T, Abbasi S. Wind energy: increasing deployment, rising environmental concerns. Renew Sustain Energy Rev 2014;31: 270-88. 
Power production and environmental opinions - Environmentally motivated resistance to windpower in Sweden Authors: Haikola, S \& Anshelm, J

[82] Corvellec H. Industrialisering och nyliberal kommersialisering av blåsiga platser. GRI report 2006:3. Gothenburg: School of Business, Economics and Law, Gothenburg University; 2006.

[83] Mels S, Aronsson L. Planering och kommunikation kring vindkraftverk i havet. Stockholm: Vindval, Swedish Environmental Protection Agency; 2010.

[84] Böhler T.Vindkraft, landskap och mening. En studie om vindkraft och människans rumsliga preferenser (diss.). Gothenburg: Gothenburg University; 2004.

[85] Stenson H, Hammarstrand J. Det blåser kring vindkraft! En kontroversstudie om vindkraftsetablering på västkusten". Trollhättan: University West; 2012.

[86] Waldo $\AA$. Offshore wind power in Sweden: a qualitative analysis of attitudes with particular focus on opponents. Energy Policy 2012;41: 692-702.

[87] Khan J. Local politics of renewable energy: project planning, siting conflicts and citizen participation (diss.). Lund: Lund University; 2004.

[88] Westling S. Wind power controversies: a case study of Ödeshög. Linköping: Linköping University; 2012.

[89] Waldo $\AA$, Klintman M. Attityder och delaktighet vid etablering av vindkraft till havs. Stockholm: Vindval, Swedish Environmental Protection Agency; 2010.

[90] Szarka J. Wind power, discourse coalitions and climate change: Breaking the stalemate? Eur Environ 2004;14: 317-30.

[91] Szarka J. Wind power in europe: politics, business and society. Basingstroke: Palgrave Macmillan; 2007.

[92] Nadaï A. "Planning", "siting" and the local acceptance of wind power: some lessons from the French case. Energy Policy 2007;35: 2715-26.

[93] Devlin E. Factors affecting public acceptance of wind turbines in Sweden (diss.). Lund: Lund University; 2002.

[94] Jørgensen U, Karnøe P. The Danish wind turbine story: technical solutions to political visions? In: Rip A, et al., editors. Managing Technology in Society. London: Pinter; 1995.

[95] Garud R, Karnøe P. Bricolage versus breakthrough: distributed and embedded agency in technology entrepreneurship. Res Policy 2003;32: 277-300. 
Power production and environmental opinions - Environmentally motivated resistance to windpower in Sweden Authors: Haikola, S \& Anshelm, J

[96] Karnöe P. The social process of competence building. Int J Technol Manag 1996;11(7-8): 770-89.

[97] Toke D. Wind power in UK and Denmark: can rational choice help explain different outcomes? Environ Politics 2002;11: 83-100.

[98] Toke D, Breukers S, Wolsink M. Wind power deployment outcomes: how can we account for the differences? Renew Sustain Energy Rev 2008;12: 1129-47.

[99] Klaassen G, Miketa A, Larsen K, Sundqvist T. The impact of R\&D on innova- tion for wind energy in Denmark, Germany and the United Kingdom. Ecol Econ 2005;54: 227-40.

[100] Bergek A, Jacobsson S. The emergence of a growth industry: a comparative analysis of the German, Dutch and Swedish wind turbine industries. In: Metcalfe D, Cantner U, editors. Change, transformation and development. Heidelberg: Physica-Verlag; 2003.

[101] Pettersson M, Ek K, Söderholm K, Söderholm P. Wind power planning and permitting: comparative perspectives from the Nordic countries. Renew Sustain Energy Rev 2010;14: 3116-23.

[102] Walker G, Cass N. Carbon reduction, "the public" and renewable energy: engaging with sociotechnical configurations. Area 2007;39: 458-69.

[103] Nolden C. Governing community energy: feed-in tariffs and the development of community wind energy schemes in the United Kingdom and Germany. Energy Policy 2013;63: 543-52.

[104] Jobert A, Laborgne P, Mimler S. Local acceptance of wind energy: factors of success identified in French and German case studies. Energy Policy 2007;35: 2751-60.

[105] Warren C, McFadyen M. Does community ownership affect public attitudes to wind energy? A case study from South-West Scotland Land Use Policy 2010;27: 204-13.

[106] Enevoldsen P, Sovacool B. Examining the social acceptance of wind energy: practical guidelines for onshore wind project development in France. Renew Sustain Energy Rev 2016;53: 178-84.

[107] Devine-Wright P. Beyond NIMBYism: towards an integrated framework for understanding public perceptions of wind energy. Wind Energy 2005;8: 125-139.

[108] Wüstenhagen R, Wolsink M, Bürer M. Social acceptance of renewable energy innovation: an introduction to the concept. Energy Policy 2007;35:2683-91.

[109] Bell D, Gray T, Haggett C. The social "gap" in wind farm siting decisions: explanations and policy responses. Environ Politics 2005;14: 460-77. 
Power production and environmental opinions - Environmentally motivated resistance to windpower in Sweden Authors: Haikola, S \& Anshelm, J

[110] Aitken M. Wind power and community benefits: challenges and opportu- nities. Energy Policy 2010;38: 6066-75.

[111] Bergek A. Levelling the playing field? The influence of national wind power

[112] Anshelm J. Kraftproduktion och miljöopinion. Kritiken av vindkraftens miljöpåverkan och den som riktats mot övriga kraftslag. Stockholm: Vindval, Swedish Environmental Protection Agency; 2013.

[113] Poortinga W, et al. Public perceptions of nuclear power, climate change and energy options in Britain: summary findings of a survey conducted during October and November 2005. Norwich: Centre for Environmental Risk; 2006.

[114] European Commission. Special Eurobarometer: Attitudes towards energy; 2006.

[115] Bittan GG. Wind, energy, landscape: reconciling nature and technology. Philos Geogr 2001;4: $169-84$.

[116] Pasqualetti $M, J$, et al. Wind power in view: energy landscapes in a crowded world. San Diego: Academic Press; 2002.

[117] Saito Y. Machines in the ocean: the aesthetics of wind farms. Contemp aesthet 2004;2.

[118] Boone J. The aesthetic dissonance of industrial wind machines. Contemp aesthet 2005;3.

[119] Jonsson L, Troell J. Skandal att myndigheterna struntar i människors oro. Dagens Nyheter 30/12; 2010.

[120] Mels T. Globalism, particularism, and the greening of neoliberal energy landscapes. In: Bradely K, Hedrén J, editors. Green utopianism: politics, perspectives and micro-practices. London: Routledge; forthcoming.

[121] Warren C, et al. "Green on green": public perceptions of wind power in Scotland and Ireland. J Environ Plan Manag 2005;48: 853-7.

[122] Petrova M. NIMBYism revisited: Public acceptance of wind energy in the United States. WIREs Clim Chang 2013;4: 575-601.

[123] van der Horst D, Toke D. Exploring the landscape of wind farm developments; local area characteristics and planning process outcomes in rural England. Land Use Policy 2010;27: 214-21.

[124] Haggett C. Implications of alternative mitigation responses: renewable energy. In: Lever-Tracey C, editor. Handbook of climate change and society. London: Routledge; 2009. 
Power production and environmental opinions - Environmentally motivated resistance to windpower in Sweden Authors: Haikola, S \& Anshelm, J

[125] Haggett C. Understanding public responses to offshore wind power. Energy Policy 2011;39: 50310.

[126] Devine-Wright P. Rethinking Nimbyism: the role of place attachment and place identity in explaining place-protective action. J Community Appl Soc Psychol 2009;6: 426-41.

[127] Agterbosch S, Glasberg P, Vermeulen W. Social barriers in wind power development in the Netherlands: perceptions of wind power entrepeneurs and local civil servants of institutional and social conditions in realizing wind power projects. Renew Sustain Energy Rev 2008;11: 1025-55.

[128] Johansson M, Laike T. Intention to respond to local wind turbines: the role of attitudes and visual perception. Wind Energy 2007;10: 435-51.

[129] Lundgren LJ. Staten och naturen. Naturskyddspolitik i Sverige. Brottby: Kassandra; 2011. p. 1869935.

[130] Anshelm J. Det vilda, det vackra och det ekologiskt hållbara. Om opi- nionsbildningen i Svenska Naturskyddsföreningens tidskrift Sveriges Natur 1943-2002. Umeå: Umeå University; 2004.

[131] Ansolabehere S, Konisky D. Public attitudes toward construction of new power plants. Public Opin Q 2009;73(3): 566-77.

[132] van der Horst D. NIMBY or not? Exploring the relevance of location and the politics of voiced opinions in renewable energy siting controversies Energy Policy 2007;35: 2705-14. 